\title{
Karakter Morfologi Rambut Kelompok Cervidae Indonesia
}

\author{
Hair Morphological of Indonesia Cervidae \\ Ni Luh Putu Rischa Phadmacanty ${ }^{1}$, Zulkurnia Irsaf ${ }^{2}$, Gono Semiadi ${ }^{1}$ \\ 'Bidang Zoologi, Pusat Penelitian Biologi, Lembaga Ilmu Pengetahuan Indonesia, \\ Cibinong, Bogor, Jawa Barat \\ ${ }^{2} J u r u s a n$ Biologi, Fakultas Matematika dan Ilmu Pengetahuan Alam, Universitas Tadulako, \\ Palu, Sulawesi Tengah \\ Email: rischa.phadmacanty@gmail.com
}

Naskah diterima: 9 Juli 2019, direvisi: 22 Agustus 2019, disetujui: 24 Maret 2020

\begin{abstract}
Identification through animal hair characters has a significant role in forensic work, given the high level of animal trade in Indonesia, one of which is the deer family (Cervidae). Native to Indonesia, there are Rusa timorensis (Javan deer), Rusa unicolor (Sambar deer), Muntiacus muntjak (Barking deer) and Axis kuhlii (Bawean deer). Until now, no information on the morphological characters of Indonesian cervidae's hairs was studied. In this study, we used 30 shaft/individual/species from Javan deer ( 8 individuals), Sambar deer (5 individuals), Barking deer (5 individuals) and Bawean deer (5 individuals) from Museum Zoologicum Bogoriense (MZB) and field collections. Hairs were analyzed macroscopically and microscopically, with several parameters of morphology, cuticular structure, medulla, cross-section, and medullary index. The result showed that the distinctive characters of this family were the filled lattice medulla structure, and each species has a specific character that can be used for species identification.
\end{abstract}

Key words: Cervidae; deer; hairs; macroscopic; miroscopic; structure

\begin{abstract}
Abstrak
Identifikasi karakter rambut satwa memegang peran penting dalam kegiatan forensik mengingat tingginya tingkat perdagangan satwa di Indonesia, salah satunya adalah kerabat rusa (Cervidae). Indonesia memiliki empat jenis rusa, yaitu Rusa timorensis (rusa jawa), Rusa unicolor (rusa sambar), Muntiacus muntjak (muncak) dan Axis kuhlii (rusa bawean). Hingga saat ini gambaran morfologi rambut rusa Indonesia belum ada. Untuk itu perlu dibangun basis data untuk menunjang kegiatan forensik keluarga Cervidae. Dalam penelitian ini digunakan 30 helai/individu/spesies dari empat spesies rusa meliputi rusa jawa ( 8 individu), rusa sambar ( 5 individu), muncak (5 individu) dan rusa bawean (5 individu) dari koleksi spesimen kulit yang dideposit di Museum Zoologicum Bogoriese (MZB) dan koleksi alam. Rambut yang diperoleh dianalisa secara makroskopis dan mikroskopis melalui parameter morfologi, struktur kutikula, medula, penampang melintang dan indeks medula. Hasil diperoleh bahwa karakter khusus dari famili Cervidae yaitu memiliki struktur filled lattice pada medula. Selain itu, setiap spesies Cervidae memiliki karakter khusus pada rambutnya yang dapat digunakan untuk membedakan tiap jenis dari famili tersebut.
\end{abstract}

Kata kunci: Cervidae; makroskopis; mikroskopis; rambut; rusa; struktur 


\section{Pendahuluan}

Perdagangan satwa liar menempati posisi ke dua dalam perdagangan internasional setelah obat-obatan. Satwa liar yang diperdagangkan biasanya hanya berupa bagian dari tubuh satwa, yang kadang sulit untuk dapat langsung diidentifikasi asal satwanya. Untuk itu identifikasi melalui sebagian tubuh satwa sangatlah penting dilakukan (Sahajpal et al. 2009). Metode modern dalam bidang forensik yang banyak dilakukan adalah dengan analisa molekuler (Oien 2009), namun metode ini cukup mahal. Metode yang cukup murah adalah secara mikroskopis melalui telaahan anatomi atau morfologi dari salah satu bagian tubuh satwa (Lungu et al. 2007),

Setiap spesies satwa memiliki karakter rambut unik yang dapat digunakan untuk identifikasi, melalui telaah struktur, ukuran, bentuk, warna, dan sisik kutikula rambut. Sisik kutikula rambut memiliki bentuk dan dimensi yang berlainan yang mencirikan suatu jenis satwa tertentu (Short 1978). Untuk itu identifikasi mamalia melalui karakter rambut dapat diterapkan dalam studi forensik, taksonomi dan ekologi. Selain itu sifat rambut yang tidak mudah terdegradasi memungkinkan rambut dapat digunakan untuk mengetahui jenis mangsa lewat analisa feses predator (Anwar et al. 2012).

Indonesia memiliki empat spesies rusa, yaitu Rusa timorensis (rusa jawa), Rusa unicolor (rusa sambar), Muntiacus muntjak (muncak) dan Axis kuhlii (rusa bawean). Tingginya tingkat perburuan ilegal, kerusakan habitat dan penurunan luasan habitat merupakan tekanan yang menyebabkan populasi rusa di Indonesia menurun setiap tahunnya. Berdasarkan Peraturan Menteri Lingkungan Hidup dan Kehutanan Republik Indonesia Nomor P 106/MENLHK/SETJEN/ KUM.1/12/2018, tentang Jenis Tumbuhan dan Satwa yang Dilindungi, keempat jenis satwa tersebut termasuk dilindungi. Sedangkan dalam catatan International Union for Conservation of Nature (IUCN), rusa jawa dan rusa sambar berstatus vulnerable, muncak berstatus least concern, sedangkan rusa bawean yang merupakan spesies endemik berstatus critically endangered. Diantara keempat jenis tersebut, rusa bawean masuk dalam daftar Apendiks I CITES (Hedges et al. 2015; Timmins et al. 2015; Timmins et al. 2016).

Kemampuan identifikasi jenis sitaan melalui pengamatan morfologi rambut menjadi sangat penting dalam upaya pengungkapan kasuskasus pelanggaran yang berhubungan dengan pemanfaatan secara illegal atas sebagian tubuh satwa. Hingga saat ini publikasi tentang gambaran morfologi dari rambut kelompok rusa yang ada di Indonesia belum ada dan perlu dibangun basis datanya. Tujuan dari penelitian ini adalah untuk mendeskripsi morfologi rambut pada kelompok rusa (Cervidae) yang ada di Indonesia.

\section{Materi dan Metode}

Sampel rambut diperoleh dari koleksi spesimen kulit yang dideposit di Museum Zoologicum Bogoriese (MZB), Pusat Penelitian Biologi-LIPI dan hasil koleksi di lapangan. Semua analisa dilakukan di laboratorium Pengelolaan dan Reproduksi Satwa Liar serta laboratorium Parasitologi, Bidang Zoologi, Pusat Penelitian Biologi LIPI, Cibinong. Sampel yang digunakan terdiri dari rambut empat spesies rusa (Cervidae) dewasa yang ada di Indonesia, meliputi rusa jawa/Rusa timorensis (8 individu), rusa sambar/ Rusa unicolor (5 individu), muncak/Muntiacus muntjak (5 individu) and rusa bawean/Axis kuhlii (5 individu). Rambut yang dikoleksi yaitu guard hair tanpa folikel yang diambil dari bagian dorsal, yaitu dorsal depan, tengah dan belakang. Pengambilan berdasarkan posisi tubuh yang berbeda ini dilakukan mengingat setiap posisi memiliki perbedan fitur dan konsistensi rambut yang spesifik (Tridico et al. 2014).

Analisa makroskopis dilakukan dengan mengamati tiap helai rambut (30 helai/individu spesies) terhadap warna, struktur dan tekstur rambut. Analisa medula dilakukan dengan cara meletakkan guard hair pada object glass, kemudian ditetesi gliserin dan ditutup dengan cover glass yang selanjutnya diamati di bawah mikroskop compound (Nikon Opiphot, Japan) yang terhubung camera digital (Canon Powershot S5IS) pada pembesaran 200 kali. Analisa kutikula dan penampang melintang dilakukan menggunakan Scanning Electron Microscope/SEM (Jeol, Japan) dengan terlebih dahulu dicuci dengan aseton, 
kemudian ditempelkan pada stub (Hess et al. 1985). Struktur medula, kutikula dan penampang melintang diklasifikasikan berdasarkan Teerink (2003). Pola kutikula merujuk pada Petraco and Kubic (2004). Analisa kuantitatif, dilakukan melalui pengukuran ketebalan rambut dan ketebalan medula, kemudian dianalisa indeks medulanya dengan rumus: (tebal medula/tebal rambut) x $100 \%$.

\section{Hasil dan Pembahasan}

Analisa secara makroskopis pada rambut Cervidae Indonesia menunjukkan sedikitnya variasi yang terlihat diantara ke empat jenis rusa. Warna rambut rusa jawa dan rusa bawean memiliki gradasi dengan warna putih-krem pada bagian distal, cokelat pada bagian medial dan cokelat tua-hitam pada bagian proximal. Sedangkan pada rusa sambar dan muncak memiliki warna cokelat terang tanpa adanya gradasi (Tabel 1, Gambar 1). Sebagian besar struktur rambut cervidae Indonesia bergelombang-lurus, namun untuk rusa jawa semua sampel yang diperoleh berstruktur bergelombang (Gambar 1). Diantara keempat jenis rusa, hanya rambut rusa jawa yang secara makroskopis mudah diidentifikasi secara langsung. Struktur rambut bergelombang-lurus umum ditemukan pada famili Cervidae, seperti pada Hydropotes inermis, Capreolus pygargus, Dama dama, Cervus elaphus dan Capreolis capreolus (Lee et al. 2013; De Marinis \& Asprea 2006).

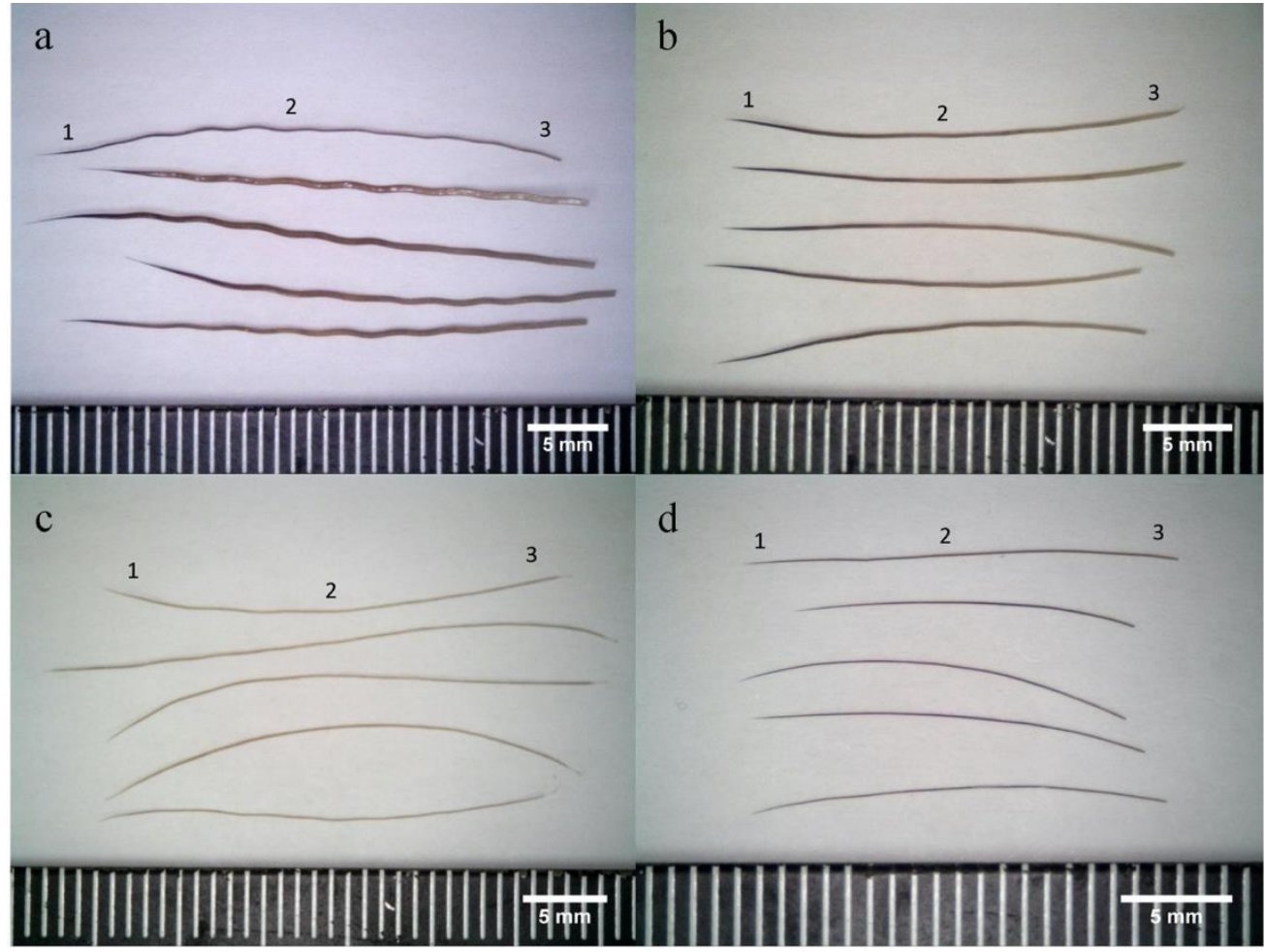

Gambar 1. Struktur makroskopis rambut cervidae, a. Rusa jawa; b. Rusa sambar; c. Rusa bawean; d. Muncak. (1). Ujung, (2). Tengah, (3). Pangkal.

Tabel 1. Struktur makroskopis rambut cervidae

\begin{tabular}{llll}
\hline Parameter & $\begin{array}{l}\text { Rusa timorensis } \\
\text { (Rusa jawa) }\end{array}$ & $\begin{array}{l}\text { Rusa unicolor } \\
\text { (Rusa sambar) }\end{array}$ & $\begin{array}{l}\text { Axis kuhlii } \\
\text { (Rusa bawean) }\end{array}$ \\
\hline Morfologi & & & $\begin{array}{l}\text { Muntiacus muntjak } \\
\text { (Muncak) }\end{array}$ \\
\hline Warna & $\begin{array}{l}\text { Putih /krem pada bagian distal, } \\
\text { cokelat muda pada bagian } \\
\text { medial, dan cokelat tua-hitam } \\
\text { pada bagian proximal }\end{array}$ & $\begin{array}{l}\text { Cokelat muda tanpa } \\
\text { gradasi }\end{array}$ & $\begin{array}{l}\text { Putih /krem pada bagian distal, } \\
\text { cokelat muda pada bagian } \\
\text { medial, dan cokelat tua-hitam } \\
\text { pada bagian proximal }\end{array}$ \\
\hline Tekstur & Kasar & Kasar & Halus \\
\hline Struktur & Gelombang & Gelombang-lurus & Gelombang-lurus \\
\hline
\end{tabular}



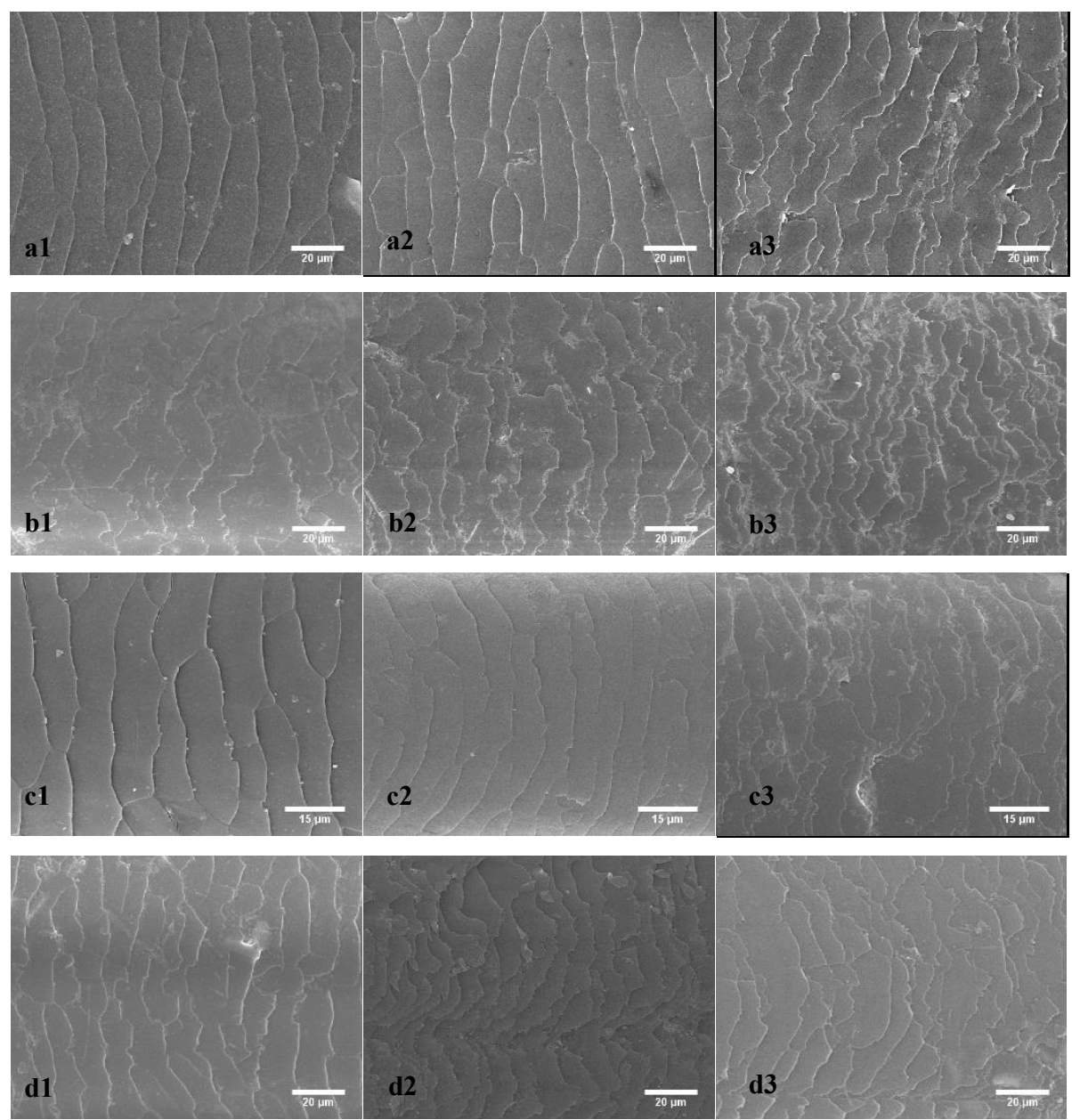

Gambar 2. Hasil SEM sisik kutikula . a. Rusa jawa; b. Rusa sambar; c. Rusa bawean; d. Muncak. (1). Pangkal, (2). Tengah, (3). Ujung.

Hasil analisa SEM menujukkan mayoritas posisi sisik rambut Cervidae Indonesia adalah transversal, kecuali pada rusa bawean yang memiliki pola sisik kombinasi antara transversal dan diagonal (Gambar 2), sedangkan pola sisik adalah antara mozaic dan wavys, namun terdapat perbedaan pola gelombang pada tiap jenis rusa. Pola regular mozaic ditemukan pada bagian pangkal hingga tengah rambut rusa jawa dan rusa bawean, sedangkan pola irregular wave ditemukan pada seluruh bagian rambut pada rusa sambar dan muncak, serta bagian ujung rambut rusa jawa dan rusa bawean (Gambar 2).

De Marinis \& Asprea (2006) melaporkan bahwa pada kelompok Cervidae asal Eropa yaitu Dama dama dan Cervus elaphus memiliki pola sisik regular wave. Sedangkan pada kelompok Cervidae dari Amerika Serikat dan China yaitu Odocoileus virginiatus, C. elaphus, C. albirotris, dan C. nippon memiliki pola sisik mozaik (Sessions et al. 2009; Cheng et al. 2007). Perbedaan pola sisik dapat terjadi karena perbedaan bagian rambut yang dianalisa. Dalam penelitian ini menunjukkan adanya perubahan pola sisik dari bagian pangkal hingga ujung rambut pada rusa jawa dan rusa bawean. Perbedaan pola sisik kutikula dalam satu helaian rambut juga dijumpai pada beberapa spesies seperti di famili Bovidae yaitu Tragelaphus scriptus, T. spekei, dan Cephalophus monticola. Sedangkan struktur kutikula irregular wave yang merata dari pangkal hingga ujung rambut yang dimiliki oleh rusa sambar dan muncak, juga ditemukan pada beberapa famili Bovidae lainnya yaitu Hippotragus equinus dan Kobus vardonii. Pola sisik yang mirip dengan rusa bawean dengan posisi sisik bervariasi dari trasversal dan diagonal yang ditemukan pada famili Bovidae tampak pada C. natalensis (Keogh 1983).

Struktur medula pada Cervidae Indonesia menunjukkan hasil yang konstan dari bagian distal hingga proksimal. Medula Cervidae menunjukkan tidak ada perbedaan antar spesies dengan struktur 
homogen, multiseluler dan filled lattice (Tabel 2, Gambar 3). Hal ini senada dengan laporan De Marins \& Asprea (2006) dan Joshi et al. (2012), dimana medula pada beberapa kelompok ungulata tidak dapat dijadikan sebagai kunci identifikasi hingga tingkat spesies karena strukturnya yang mirip. Selain itu struktur medula tidak terpengaruh oleh faktor lingkungan, namun terbentuk karena sejarah evolusinya (Chernova 2002). Struktur medula yang homogen juga ditemukan pada Artiodactyla lainnya, namun hanya pada tingkat subfamili. Misalnya pada Bovidae, subfamili Caprinae memiliki struktur medula filled lattice parsial sedangkan pada subfamili Bovinae menunjukkan struktur multisteriat (De Marinis and Asprea, 2006). Konsistensi medula pada Cervidae menunjukkan bahwa struktur medula filled laticce yang homogen merupakan karakter khusus dari famili ini,

Untuk penampang melintang, rambut Cervidae Indonesia memiliki empat struktur yang berbeda yaitu oblong, oval, circuler dan triangular. Penampang melintang rambut rusa jawa berbentuk oval pada bagian pangkal, oblong pada bagian tengah sedangkan ujung rambut berbentuk tringular. Pada rusa sambar memiliki penampang melintang rambut berbentuk oval pada bagian pangkal dan tengah, sedangkan bagian ujung berbentuk triangular. Muncak memiliki penampang melintang rambut berbentuk oval, sedangkan rusa bawean berbentuk circular. Bentuk tersebut konsisten dari pangkal hingga ujung rambut.

Bentuk penampang melintang rambut tergambar dalam struktur makroskopis rambut tiap jenis (Gambar 4). Rusa jawa tampak pipih secara makroskopis sehingga sesuai dengan struktur penampang melintangnya yang berbentuk oblong. Selain struktur penampang melintang tersebut (oblong, oval, circuler dan triangular), masih banyak struktur lainnya yang membedakan tiap jenis, misalnya pada salah satu jenis bovidae Raphicerus sharpei memiliki penampang melintang concavo-covex. Namun demikian struktur penampang melintang rambut dapat berbeda tiap posisi dalam satu helaian rambut seperti pada Raphicerus campestris yang memiliki bentuk kombinsi oblong, concavo convex, dumbbell, triangular dan bentuk bumerang (Keogh 1983).

Berdasarkan potongan melintang juga diketahui adanya perbedaan jumlah baris sel
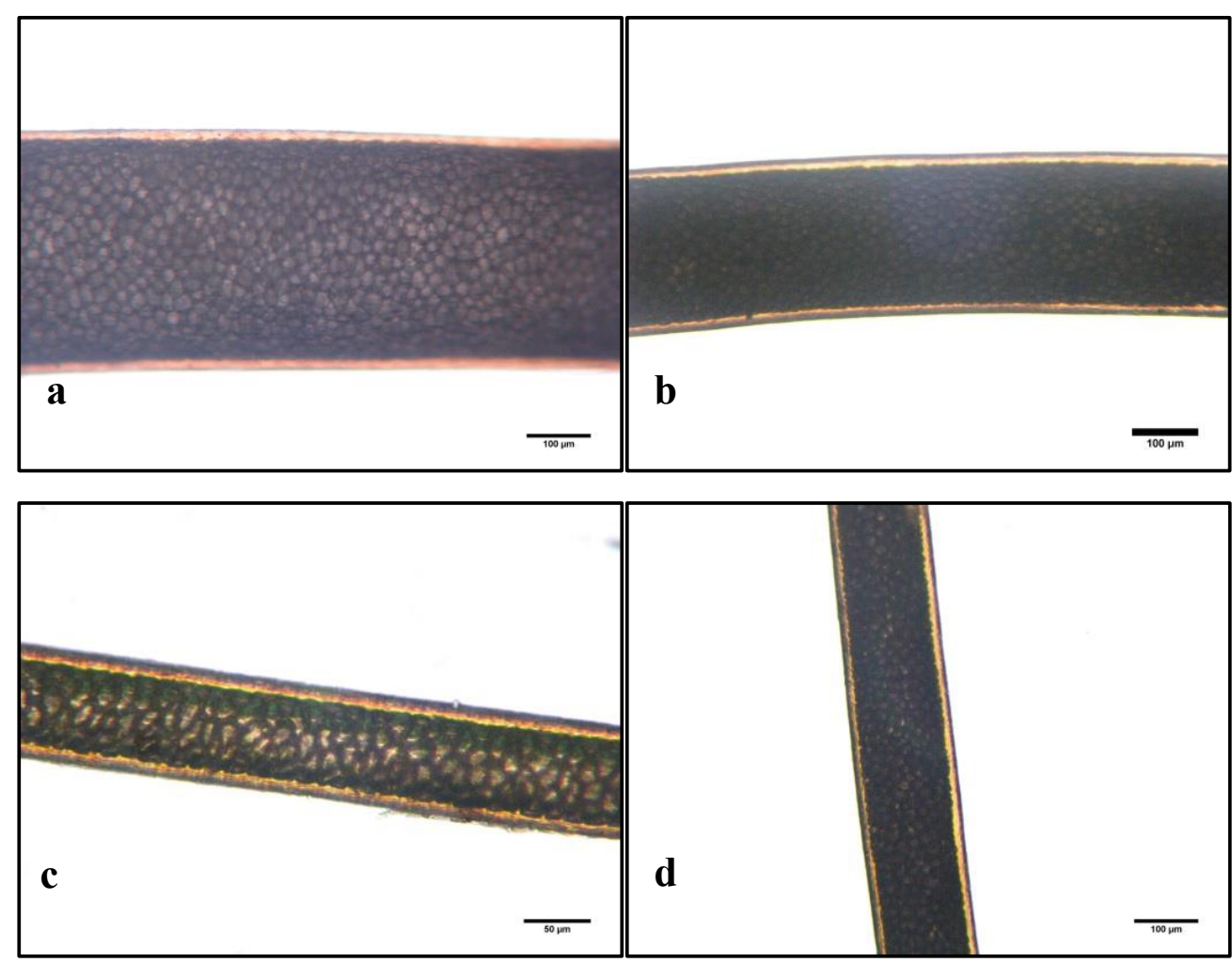

Gambar 3. Struktur medula filled lattice pada bagian medial rambut Cervidae (a) Rusa timor; (b) Rusa sambar; (c) Rusa bawean; (d) Muncak 
penyusun medula. Rusa jawa dan rusa bawean menunjukkan adanya satu baris sel poligonal, muncak memiliki banyak baris sel poligonal, sedangkan rusa sambar memiliki satu baris sel poligonal pada bagian pangkal rambut, kemudian banyak baris pada bagian tengah dan ujung rambut (Tabel 2, Gambar 4). Penelitian Cheng, et al. (2007) terhadap beberapa jenis Cervidae antara lain Rusa unicolor, Cervus albirotris dan $C$. elaphus menunjukkan multi layer sel, $C$. nippon dengan multi layer sel, dan $C$. elaphus dengan dua baris sel. Konsistensi jumlah baris sel medula pada rusa sambar yang dilaporkan Cheng et al. (2007) dan dalam penelitian ini, menunjukkan bahwa jumlah baris sel suatu spesies memiliki konsistensi sama halnya dengan struktur medula. Dengan demikian morfologi potongan melintang dapat digunakan sebagai karakter identifikasi hingga ketingkat jenis.

Berdasarkan morfometri, rusa jawa memiliki diameter rambut terbesar dibandingkan dengan Cervidae Indonesia lainnya (Tabel 2, Gambar 5), dengan kecenderungan diameter rambut pada rusa timor lebih besar $18 \%$ dibandingkan dengan rusa sambar. Hasil pengamatan De Marinis and Asprea (2006) melaporkan bahwa rata-rata diameter rambut kelompok Cervidae Eropa adalah 232 um. Nilai tersebut jauh lebih besar dibandingkan dengan diameter rambut hasil penelitian ini yang rata-rata hanya 63,32 um. Banyak faktor yang

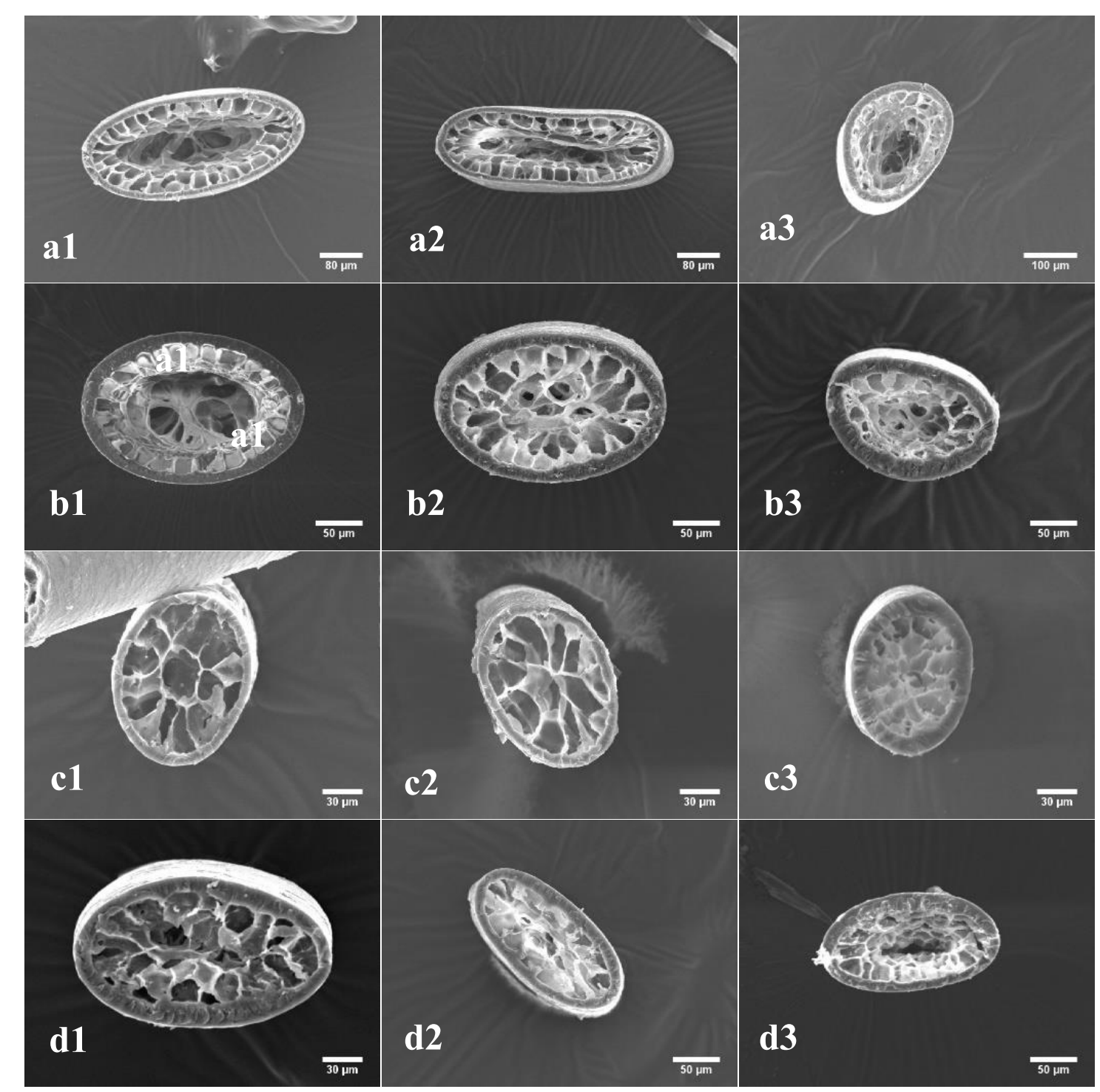

Gambar 4. Penampang melintang rambut Cervidae (a) Rusa jawa, 1. Pangkal (1 layer), 2. Tengah (1 layer), 3. Ujung (1 layer); (b) Rusa sambar, 1. Pangkal (1 layer), 2. Tengah (multi layer), 3. Ujung (multi layer); (c) Rusa bawean, 1. Pangkal (1 layer), 2. Tengah (1 layer), 3. Ujung (1 layer); (d) Muncak, 1. Pangkal (multi layer), 2. Tengah (multi layer), 3. Ujung (multi layer). 
Tabel 2. Karakter mikroskopis rambut cervidae

\begin{tabular}{|c|c|c|c|c|}
\hline Parameter & $\begin{array}{l}\text { Rusa timorensis } \\
\text { (Rusa jawa) }\end{array}$ & $\begin{array}{l}\text { Rusa unicolor } \\
\text { (Rusa sambar) }\end{array}$ & $\begin{array}{l}\text { Axis kuhlii } \\
\text { (Rusa bawean) }\end{array}$ & $\begin{array}{l}\text { Muntiacus muntjak } \\
\text { (Muncak) }\end{array}$ \\
\hline \multicolumn{5}{|l|}{ Kutikula } \\
\hline Posisi sisik & Transvesal & Transvesal & Transvesal-diagonal & Transvesal \\
\hline Pola sisik & $\begin{array}{l}\text { Regular mosaic } \\
\text { irregular wave }\end{array}$ & - Iregular wave & $\begin{array}{l}\text { Regular mosaic- } \\
\text { irregular wave }\end{array}$ & Iregular wave \\
\hline Margin sisik & Smooth, rippled & Smooth, rippled & Smooth, rippled & Smooth, rippled \\
\hline Jarak antar sisik & Near-distant & Near-distant & Near-distant & Near-distant \\
\hline Jumlah sisik tiap 100 um & $12,13 \pm 1,1$ & $11,6 \pm 1,8$ & $13,7 \pm 1,9$ & $12,6 \pm 1,6$ \\
\hline \multicolumn{5}{|l|}{ Medulla } \\
\hline Komposisi & Multicellular & Multicellular & Multicellular & Multicellular \\
\hline Struktur & Filled lattice & Filled lattice & Filled lattice & Filled lattice \\
\hline Margin & Scalloped & Scalloped & Scalloped & Scalloped \\
\hline \multicolumn{5}{|l|}{ Penampang melintang } \\
\hline Bentuk & $\begin{array}{l}\text { Pangkal: Oval } \\
\text { Tengah: Oblong } \\
\text { Ujung; Triangular }\end{array}$ & $\begin{array}{l}\text { Pangkal: Oval } \\
\text { Tengah: Oval } \\
\text { Ujung; Triangular }\end{array}$ & $\begin{array}{l}\text { Pangkal: Sirkular } \\
\text { Tengah: Sirkular } \\
\text { Ujung; Sirkular }\end{array}$ & $\begin{array}{l}\text { Pangkal: Oval } \\
\text { Tengah: Oval } \\
\text { Ujung; Oval }\end{array}$ \\
\hline Jumlah layer & $\begin{array}{l}\text { Pangkal: } 1 \text { layer } \\
\text { Tengah: } 1 \text { layer } \\
\text { Ujung: } 1 \text { layer }\end{array}$ & $\begin{array}{l}\text { Pangkal: } 1 \text { layer } \\
\text { Tengah: Multi layer } \\
\text { Ujung: Multi ayer }\end{array}$ & $\begin{array}{l}\text { Pangkal: } 1 \text { layer } \\
\text { Tengah: } 1 \text { layer } \\
\text { Ujung: } 1 \text { layer }\end{array}$ & $\begin{array}{l}\text { Pangkal: Multi layer } \\
\text { Tengah: Multi layer } \\
\text { Ujung: Multi layer }\end{array}$ \\
\hline
\end{tabular}

mempengaruhi ketebalan rambut, meliputi spesies, habitat, level testosteron pada hewan jantan, metabolisme dan nutrisi (Davis et al. 2010; Jones et al. 1994). Dengan demikian ketebalan rambut tidak dapat dijadikan sebagai kunci identifikasi suatu jenis sebagaimana juga disampaikan oleh Perrin and Campbell (1980).

Dalam hal ukuran medula, pada rambut Cervidae Indonesia cukup lebar. Selain diameter rambut, diameter medula rambut pada rusa jawa juga sekitar 25\% lebih besar daripada rusa sambar. Sehingga besarnya ukuran satwa tidak dapat menjadi acuan ketebalan rambut satwa tersebut. Secara ukuran tubuh, terdapat perbedaan ukuran tinggi gumba rusa sambar yang dapat mencapai 160 $\mathrm{cm}$ atau hampir dua kali lebih besar dari rusa timor yang hanya berkisar antara 76-84 $\mathrm{cm}$ (Sudibyo et al. 2013; Semiadi et al. 2005). Nilai indeks medula pada rusa jawa adalah $93 \%$, rusa sambar $85 \%$, rusa bawean $81 \%$ dan muncak $88 \%$, jauh lebih tinggi bila dibandingkan dengan C. elaphus 66\% dan C. nippon 64\% (Gambar 6; Cheng, et al., 2007). Sama halnya dengan ketebalan rambut, nilai indeks medula sulit untuk digunakan sebagai

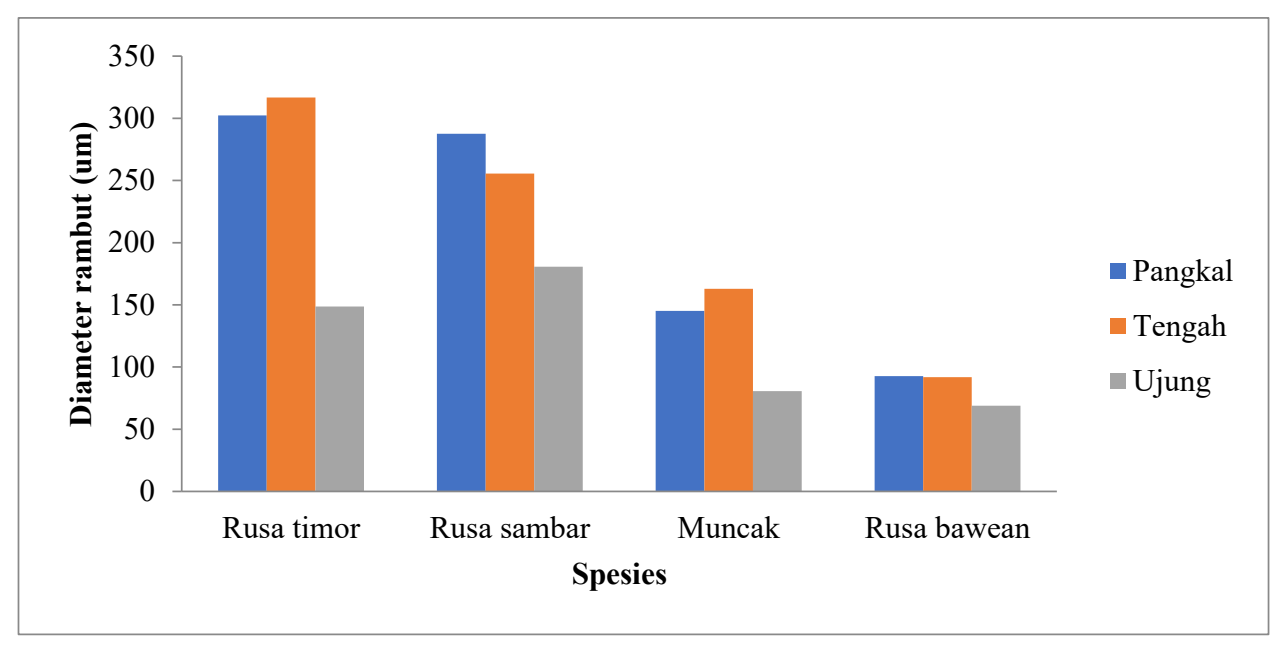

Gambar 5. Diameter rambut Cervidae Indonesia 


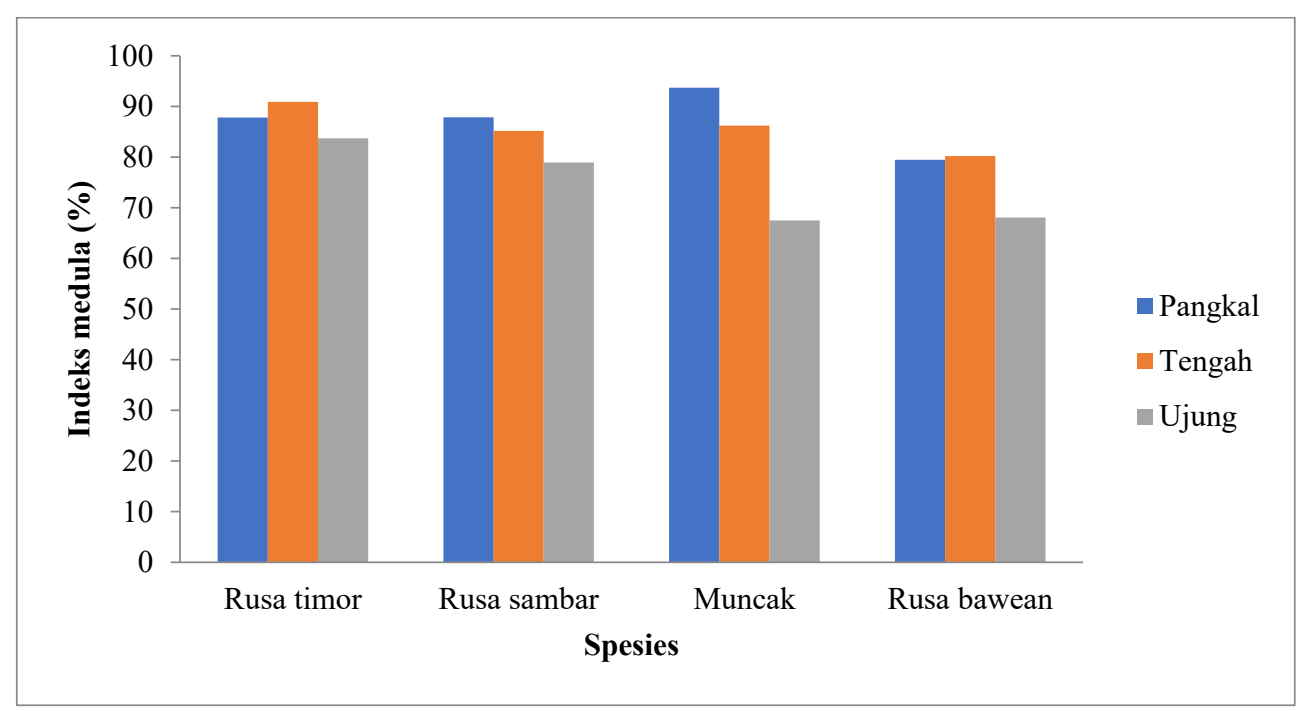

Gambar 6. Indeks medula Cervidae Indonesia

karakter identifikasi, hal ini dikarenkan adanya pengaruh umur yang memungkinkan pada umur lebih muda akan memiliki indeks medula yang lebih rendah dibandingkan umur dewasa.

\section{Kesimpulan}

Hasil penelitian menyimpulkan bahwa karakterkhusus dari famili Cervidae adalah struktur filled lattice pada medula. Ciri khas rambut yang dapat dijadikan kunci identifikasi spesies secara mudah pada rusa timor adalah bagian morfologi dan bentuk penampang melintang rambut, rusa bawean pada bagian posisi sisik kutikula dan bentuk penampang melintang, sedangkan muncak dan rusa sambar memiliki kemiripan baik dari segi makroskopis maupun mikroskopis yang membedakan keduanya adalah pada jumlah lapisan sel pada penampang melintang pangkal rambut dan diameter rambutnya.

\section{Ucapan Terima kasih}

Terimakasih kami ucapkan kepada Japan Science and Technology Agency (JST), Kyoto University, Collaboration hubs for International Research Progam (CHIRP) dengan framework Strategic International Collaborative Research Program (SICORP) dengan Pusat Penelitian Biologi-LIPI untuk tahun anggaran 2017-2018, dalam memenuhi kebutuhan bahan laboratorium. Selain itu kami ucapkan terimakasih kepada Bapak Yulianto dan Nanang Supriyatna yang membantu dalam pengambilan sampel. Ni Luh Putu Rischa Phadmacanty adalah kontributor utama dalam penulisan ini.

\section{Daftar Pustaka}

Anwar, M.B., M.H. Nadeem, M.A. Beg, A.R. Kayani, and G. Muhammad. (2012). A Photographic key for identification of mammalian hairs of prey species in snow leopard (Panthera indica) habitat of GilgitBaltistan Province of Pakistan. Pakistan Journal of Zoology. 44 (3): 37-743.

Cheng, X., T. Kang and Z. Zhao. (2007). Studies on microscopic identification of animal drug's remnant hair (3): identification of several species of cauda cervi. Journal of Natural Medicine. 61 (1): 51-55.

Chernova, O.F. (2002). Architectonic and Diagnostic Significance of Hair Cuticle. Biology Bulletin. 29(3): 238-247.

Davis, A.K. (2010). A technique for rapidly quantifying mammal hair morphology for zoological research. Folia Zoological. 59 (2): 87-92.

De Marinis, A. M. and A. Asprea. (2006). Hair identification key of wild and domestic ungulates from southern Europe. Wildlife Biology. 12(3): 305-320.

Hedges, S., Duckworth, J.W., Timmins, R., Semiadi, G. and Dryden, G. (2015). Rusa 
timorensis. The IUCNRedList of Threatened Species 2015: e.T41789A22156866. http:// dx.doi.org/10.2305/IUCN.UK.2015-2. RLTS.T41789A22156866.en. Downloaded on 14 May 2019.

Hess, W.M., Flinders J.T. Pritchett CL., and Allen J.V. (1985). Characterization of hair morphology in families Tayassuidae and Suidae with scanning electron microscopy. Journal of Mammalogy. 66: 75-84.

Keogh, H.J. (1983). A photographic reference system of the microstructure ofthe hair ofsouthern African bovids. South African Journal of Wildlife Research. 13(4): 89-132.

Lee, E., T.Y. Choi, D. Woo, M.S. Min, S. Sugita and H. Lee. (2013). Species identification key of Korean mammal hair. Journal of Veterinary Medical Science. 76(5): 667675.

Lungu, A., C. Recordati, V. Ferrazzi and D. Gallazi. (2007). Image analysis of animal hair: morphological features useful in forensic veterinary medicine. Lucrari Sciintifice Medicina Veterinara. XL: 439-446.

Joshi, H.R., S.A. Gaikwad, M.P.S. Tomar and K. Shrivastava. (2012). Comparative trichology of common wild herbivores of India. Advances in Applied Science Research. 3(6): 3455-3458.

Oien, C.T. (2009). Forensic Hair Comparison: Background Information for Interpretation. Forensic Science Communications.11(2).

Perrin, M.R and Campbell, B.S. (1980). Key to the mammals of the Andries Vosloo Kudu Reserve (eastern Cape), based on their hair morphology, for use in predator scat analysis. South Africa Tydskr.Natuurnav. 10: $1-14$.

Petraco, N. \& Kubic, T. (2004). Microscopy for Criminalist, Chemists, and Conservation. CRC Press:Washington DC.

Sahajpal, V., S.P. Goyal, R. Raza and R. Jayapal. (2009). Identification of mongoose (genus: Herpestes) species from hair through band pattern studies using discriminate functional analysis (DFA) and microscopic examination. Science and Justice. 49: 205209

Semiadi, G., I.G. M. Jaya Adi and A. Trasadiharto. (2005). Pola kelahiran rusa sambar (Cervus unicolor) di penangkaran Kalimantan Timur. Biodiversitas. 6(1): 59-62.

Sessions, B.D., W.M. Hess and W.S. Skismore. (2009). Can hair width and scale pattern and direction of dorsal scapular mammalian hair be a relatively simple means to identify species? Journal of Natural History. 3: 7-8, 489-507.

Short, H.L. (1978). Analysis of cuticular scale on hair using the scanning electron microscope. Journa

Sudibyo, M., Y. Santoso, B. Masy'ut, and T. Toharmat. (2013). Preferencesof Rusa timorensis to grasses and their body morphology andvelvet antler characteristic. Media Peternakan. 2013: 143-151.

Teerink, B.J. (2003). Hair of West European Mammals: Atlas and Identification Key. Cambridge University Press.

Timmins, R.J., Duckworth, J.W., and Hedges, S. (2016). Muntiacus muntjak. The IUCN Red List of Threatened Species 2016: e.T42190A56005589. http://dx.doi. org/10.2305/IUCN.UK.2016-1.RLTS. T42190A56005589.en. Downloaded on 14 May 2019.

Timmins, R., Kawanishi, K., Giman, B, Lynam, A., Chan, B., Steinmetz, R., Sagar Baral, H., and Samba Kumar, N. (2015). Rusa unicolor (errata version published in 2015). The IUCN Red List of Threatened Species : http://dx.doi.org/10.2305/IUCN. UK.2015- 2.RLTS.T41790A22156247. en. Downloaded on 14 Mei 2019.

Tridico, S.R., M.M. Houck, K. Paul Kirbride, M. E. Smith and C. Yates. (2014). Morphological identification of animal hair: Myths and misconceptions, possibilities and pitfalls. Forensic Science International. 238: 101107. 